Огляди літератури, оригінальні дослідження, погляд на проблему, ювілеї

уДК 616.12-008.331.1-08:616.12-005.4-008.318

DOI 10.11603/1811-2471.2019.v0.i1.10072

\title{
КОМПЛЕКСНЕ ЛІКУВАННЯ АРТЕРІАЛЬНОÏ ГІПЕРТЕНЗІЇ У ПОЄДНАННІ З ІШЕМІЧНОЮ ХВОРОБОЮ ТА ПОРУШЕННЯМИ СЕРЦЕВОГО РИТМУ
}

\author{
๑С. О. Шейко, Н. О. Кол6 \\ ДЗ «Дніпропетровська медична академія МОЗ України»
}

PEзЮМЕ. У комплексному лікуванні АГ у поєднанні з хронічною IXC найдоцільніше застосувати засоби, які мають сприятливий вплив на перебіг обох захворювань: знижувати рівень АТ, запобігати ішемії та стенокардії, інфаркту міокарда та інсульту, зменшувати ймовірність смерті, покращувати якість життя хворих. Але лікування коморбідних пацієнтів з АГ, IXC та порушеннями серцевого ритму на тлі гіпофосфатемії в даний час залишається не до кінця визначеним.

Мета - вивчення клінічної ефективності комплексного лікування пацієнтів похилого віку з артеріальною гіпертензією (АГ) в поєднанні з ішемічною хворобою серця (IXC) та порушеннями серцевого ритму на тлі гіпофосфатемії.

Матеріал і методи. Проаналізовано лікування 353 пацієнтів віком $(71,2 \pm 4,5)$ року з АГ та IXC, які отримували базисну терапію. Із них у 97 (50 жінок і 47 чоловіків) хворих з АГ, ІХC, порушеннями серцевого ритму та гіпофосфатемією зберігалися нестабільний перебіг АГ та серцево-больові напади. В основну групу включено 48 пацієнтів (25 жінок і 23 чоловіки), які приймали фіксовану комбінацію бісопрололу фумарату (5 мг) 3 амлодипіном (5 мг) і D-фруктозо-1,6-дифосфат. У групу порівняння увійшли 49 хворих (24 жінки і 25 чоловіків), у лікувальний комплекс яких D-фруктозо-1,6-дифосфат не додавали. Проведено загальноклінічне обстеження, визначення електролітів крові, електрокардіографію (ЕКГ), добове моніторування ЕКГ та артеріального тиску (АТ). Гіпофосфатемію діагностували при рівні фосфору у сироватці крові <0,9 ммоль/л.

Результати. Після лікування кількість нападів стенокардії реєстрували в 2,25 раза рідше $(1,07 \pm 0,03$ проти $2,41 \pm 1,05)$, подій депресії сегмента ST достовірно менше у хворих основної групи, порівняно 3 такими в групі

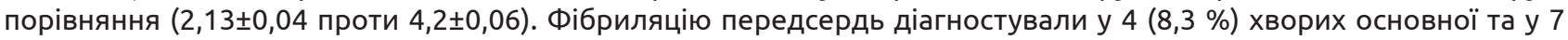
(14,2 \%) - групи порівняння, суправентрикулярну екстрасистолію - у 8 (16,6 \%) хворих основної і у 10 (20,4 \%) пацієнтів групи порівняння, шлуночкові аритмії-у 3 (6,25 \%) хворих основної групи та у 10 (20,4 \%) хворих - групи порівняння. Небезпечних для життя шлуночкових порушень ритму після лікування в основній групі не зареєстровано в жодному випадку.

Висновки. Застосування комплексної терапії при АГ з IXC, порушеннями серцевого ритму і гіпофосфатемією зі включенням в лікувальний комплекс D-фруктозо-1,6-дифосфату забезпечує істотний антиішемічний ефект, приводить до зменшення (в 2,25 раза) частоти нападів стенокардії, подій суправентрикулярної екстрасистолії, пароксизмів фібриляції передсердь, запобігає виникненню небезпечних для життя шлуночкових порушень ритму.

КЛючОВІ СлОВА: артеріальна гіпертензія; ішемічна хвороба серця; порушення серцевого ритму; фруктозо1,6-дифосфат.

Вступ. Основною медико-соціальною проблемою в Україні $\epsilon$ зростання атеросклерозу, артеріальної гіпертензії (АГ) та ішемічної хвороби серця (IXC) з порушеннями серцевого ритму. За даними державної установи «Національний науковий центр «Інститут кардіології імені академіка М. Д. Стражеска» НАМН України», серед дорослого населення України від захворювань серцево-судинної системи в 2016 році страждали 22303564 осо6 б, що складає 52,4 \% від загального населення [1]. Важливим глобальним чинником ризику розвитку кардіоваскулярної і цереброваскулярної захворюваності та раптової серцевої смерті $\epsilon$ артеріальна гіпертензія. Існує пряма кореляція між ризиком розвитку інсульту, рівнем систолічного артеріального тиску (АТ) і віком. Чим вищі вік хворого і систолічний артеріальний тиск, тим більша ймовірність розвитку порушень мозкового кровообігу як ішемічного, так і геморагічного ґенезу [2]. У структурі АГ важливе місце займає ізольова- на систолічна артеріальна гіпертензія. Аналіз Фремінгемського дослідження підтвердив роль ізольованого підвищення систолічного АТ як незалежного фактора ризику серцево-судинної патології. Зростає кількість хворих зі стабільною стенокардією напруги і на сьогодні в Україні вона становить більше 3 млн осіб [3]. Поряд з цим, одним із найпоширеніших патологічних станів серцево-судинної системи $\epsilon$ порушення серцевого ритму [4]. Пацієнтів з IXС і АГ характеризує широкий спектр надшлуночкових і шлуночкових порушень ритму серця, від екстрасистолії до фібриляції передсердь та шлуночкової тахікардії [4]. Загрозливі показники захворюваності на серцево-судинну патологію в Україні вимагають постійного удосконалення лікування таких хворих. У комплексному лікуванні пацієнтів з АГ у поєднанні $з$ хронічною IXC найдоцільніше застосовувати засоби, які мають сприятливий вплив на перебіг обох захворювань: знижують рівень АТ, запобігають 
Огляди літератури, оригінальні дослідження, погляд на проблему, ювілеї

виникненню ішемії та стенокардії, інфаркту міокарда та інсульту, зменшують ймовірність смерті, покращують якість життя хворих. Але базисна терапія не завжди дає бажані результати. Відомо, що коронарний атеросклероз призводить до дисбалансу між постачанням кисню до кардіоміоцитів і потребою в ньому, зменшення синтезу АТФ і, внаслідок цього, розвитку електрофізіологічної та функціональної дисфункції міокарда. Тому важливим компонентом терапії АГ і IXC $\epsilon$ препарати, дія яких спрямована на усунення метаболічних та електролітних порушень міокарда [5]. В останній час дослідники вивчають гіпофосфатемію. Доведено, що гіпофосфатемія - це потенційно небезпечне порушення обміну речовин, яке часто трапляється у пацієнтів з тяжкими захворюваннями, призводить до розвитку серцевої і дихальної недостатності. Встановлено взаємозв'язок між концентрацією фосфору в сироватці крові і патогенезом шлуночкової аритмії при інфаркті міокарда [6]. Оцінено потенційну клінічну роль і прогностичну значимість гіпофосфатемії у хворих з сепсисом, гострим порушенням роботи нирок [7-9]. Результати дослідження професора О. С. Сичова довели, що D-фруктозо-1,6-дифосфат доцільно включати в комплексне лікування аритмій у пацієнтів з постінфарктним кардіосклерозом і серцевою недостатністю. Абсолютним показанням до його призначення $\epsilon$ гіпофосфатемія [10]. Однак, лікування коморбідних пацієнтів з АГ, IXC та порушеннями серцевого ритму на тлі гіпофосфатемії в даний час залишається не до кінця визначеним, підходи до лікування цієї категорії хворих потребують перегляду.

Мета дослідження - вивчення клінічної ефективності комплексного лікування пацієнтів похилого віку з АГ в поєднанні з IXC та порушеннями серцевого ритму на тлі гіпофосфатемії.

Матеріал і методи дослідження. Дослідження виконано на базі терапевтичного відділення КЗ «Криворізька міська клінічна лікарня № 8» Дніпропетровської обласної ради. Проаналізовано результати обстеження та лікування 353 пацієнтів з АГ і IXC, які отримували базисну терапію. Привертає до себе увагу значний відсоток (34,6 \%) пацієнтів з ізольованою систолічною артеріальною гіпертензією серед усіх хворих з АГ. Середній вік хворих складав $(71,2 \pm 4,5)$ року. Всі пацієнти з АГ були обстежені та отримували лікування відповідно до клінічного протоколу надання медичної допомоги згідно з наказом Міністерства охорони здоров'я України від 24.05.2012 р. № 384 «Про затвердження та впровадження медико-технологічних документів зі стандартизації медичної допомоги при артеріальній гіпертензії». Згідно з клінічними рекомендаціями з АГ євро- пейського товариства гіпертензії (ESH) та європейського товариства кардіологів (ESC) 2013 року, в загальній схемі лікування АГ більшість хворих із самого початку потребують комбінованої терапії [11]. А згідно з керівництвом 2018 року Європейського товариства кардіологів і Європейського товариства гіпертензії, лікування АГ рекомендовано починати з комбінації двох препаратів в одній таблетці $[12,13]$. На сьогоднішній день відома єдина в Україні фіксована комбінація бета-адреноблокатора бісопрололу і антагоніста кальцію амлодипіну в одній таблетці. Застосування такої комбінації виправдане завдяки потенціюванню антигіпертензивного та антиішемічного ефектів обох компонентів. Бісопролол відомий як високоселективний препарат, який найчастіше застосовують для лікування IXC і АГ. Амлодипін $\epsilon$ еталонним дигідропіридиновим антагоністом кальцію тривалої дії, якому притаманний виражений дозозалежний антигіпертензивний ефект. Ефективність амлодипіну у хворих з АГ переконливо доведена у численних контрольованих дослідженнях (VALUE, ALLHAT, ASCOT, ACCOMPLISH). Діагностику та лікування хворих на IXC здійснювали згідно з уніфікованим клінічним протоколом первинної, вторинної (спеціалізованої) та третинної (високоспеціалізованої) медичної допомоги «Стабільна ішемічна хвороба серця» 2016 року № 152. Медикаментозна терапія IXC передбачала призначення антиангінальних препаратів, засобів для покращення прогнозу захворювання, а саме статинів, ацетилсаліцилової кислоти i, за показаннями, інгібіторів ангіотензинперетворювального ферменту. При наявності фібриляції передсердь хворим призначали варфарин. Для оптимізації енергетичного обміну у хворих на АГ в поєднанні з IXC і порушеннями ритму серця та для забезпечення енерговитрат призначали фруктозо-1,6-дифосфат.

Критерії включення до дослідження: АГ, в поєднанні із стабільною IXC зі стенокардією напруги II та III функціонального класу та порушеннями ритму серця на тлі гіпофосфатемії. Критерії виключення: інфаркт міокарда, нестабільна стенокардія, атріовентрикулярна блокада II і III ступенів, синоатріальна блокада, брадикардія, виражена печінкова і ниркова недостатність, гострі інфекційні захворювання, спадкова непереносимість фруктози, гіперфосфатемія.

Із когорти обстежених відібрано 97 (50 жінок і 47 чоловіків) хворих на АГ в поєднанні з стабільною IXC зі стенокардією напруги II та III функціональних класів та порушеннями ритму серця, які продовжували скаржитись на нестабільний перебіг АГ та збереження серцево-больових нападів. В основну групу включено 48 пацієнтів (25 жінок і 23 чоловіки), які приймали фіксовану комбінацію 
Огляди літератури, оригінальні дослідження, погляд на проблему, ювілеї

бісопрололу фумарату (5 мг) і амлодипіну (5 мг) та додатково фруктозо-1,6-дифосфат. До групи порівняння увійшли 49 хворих (24 жінки і 25 чоловіків), які отримували фіксовану комбінацію бісопрололу фумарату (5 мг) і амлодипіну (5 мг) без додаткового призначення фруктозо-1,6-дифосфату. В нашому дослідженні D-фруктозо-1,6-дифосфат призначали за такою схемою: 1-й день - 10 г/100 мл внутрішньовенно краплинно, наступні дні - по 5 г/50 мл внутрішньовенно краплинно. Загальна тривалість лікування препаратом складала 10 днів.

Проведено загальноклінічне обстеження хворих, визначення тиреотропного гормону, вмісту електролітів крові, електрокардіографію (ЕКГ). Гіпофосфатемію діагностували при концентрації фосфору у сироватці крові <0,9 ммоль/л. 3 метою діагностики ішемії міокарда у хворих з АГ виконували холтерівське моніторування ЕКГ. Характерними для ішемії міокарда вважали такі зміни сегмента ST: амплітуда депресії сегмента ST - не менше 1 мм (на відстані 60 мс від точки J); тривалість депресії сегмента ST не менше 1 хвилини; тривалість періоду між послідовними епізодами депресії сегмента ST - не менше 1 хвилини. Вимірювали систолічний та діастолічний артеріальний тиск, проводили добове моніторування артеріального тиску, розраховували пульсовий і середній артеріальний тиск. Обстеження виконували до початку та через 1 місяць лікування.

Для статистичної обробки даних використовували пакет програм STATISTICA v.6.1 (ліцензійний № AGAR909E415822FA) з розрахунком середньої арифметичної (М), стандартної похибки се- редньої величини (m) і 95 \% довірчого інтервалу для середньої (95 \% ДІ). Результати вважали статистично значимими при $\mathrm{p}<0,05$.

Результати й обговорення. Хворі скаржилися на стискаючий біль за грудниною і задишку (94,9 і 62,8 \% відповідно), запаморочення (26,9 \%) та швидку втомлюваність (75,6 \%). Поряд з цим пацієнти відмічали прискорене серцебиття, перебої в серцевій діяльності, відчуття нестачі повітря. Фібриляцію передсердь діагностували у 10 $(20,8 \%)$ хворих основної групи та у $9(18,4 \%)$ пацієнтів групи порівняння. Відповідно, суправентрикулярну екстрасистолію діагностували у 18 (37,5\%) і 15 (30,6 \%) хворих. Ці порушення ритму супроводжувались збільшенням розмірів лівого передсердя та зниженням його скоротливої здатності. Отже, зміни структури лівого передсердя і конфігурації його волокон $\epsilon$ передумовою для розвитку надлишкових склеротичних процесів у міокарді передсердь та формування морфологічного субстрату для порушень ритму серця. Шлуночкові порушення ритму реєстрували у 19 (39,6 \%) хворих основної групи та у $20(40,8 \%)$ пацієнтів групи порівняння. Часта, рання, групова і політопна шлуночкова екстрасистолія - це порушення ритму, що загрожують життю. В основній групі питома вага небезпечних для життя шлуночкових аритмій становила $18,1 \%$. В групі порівняння таке порушення ритму зустрічали у 15,5\% пацієнтів.

Після лікування в обох групах значно зменшилась кількість, тривалість, інтенсивність нападів стенокардії та епізодів депресії сегмента ST (рис. 1).
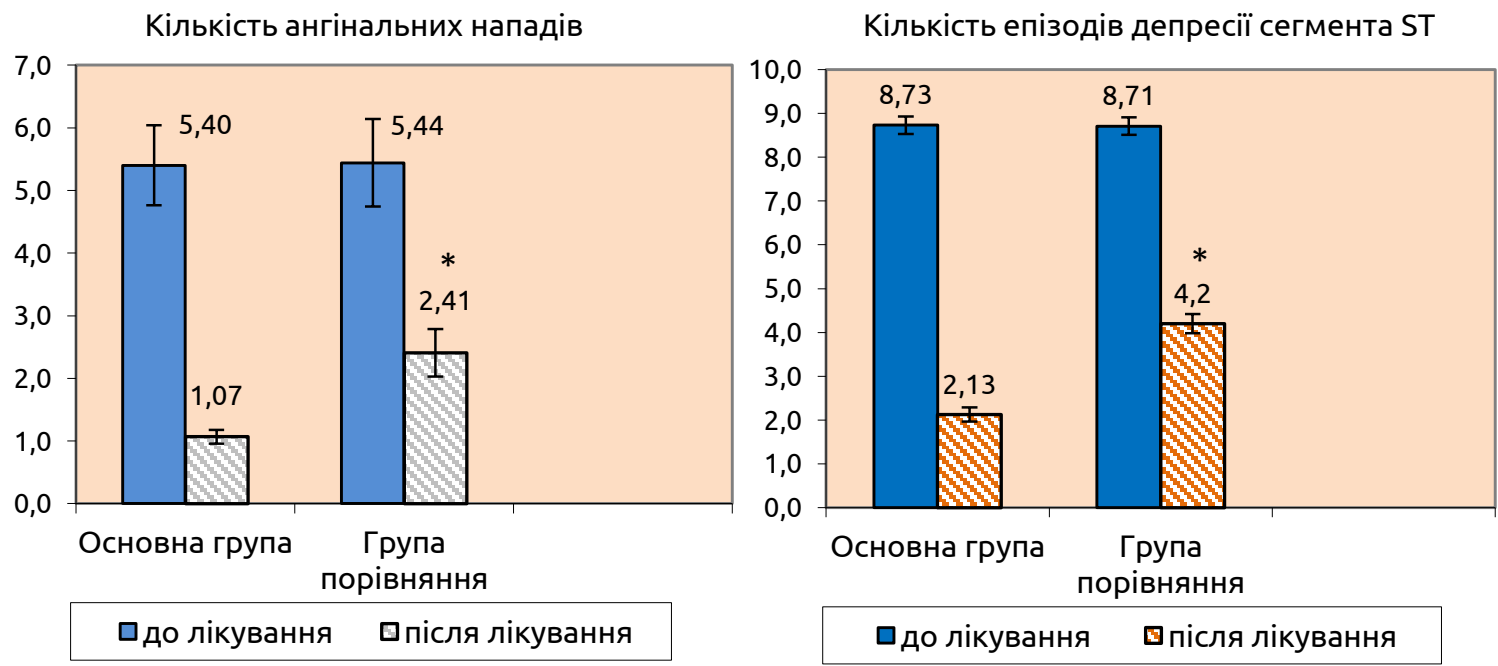

Рис. 1. Динаміка змін кількості нападів стенокардії та подій депресії сегмента ST до та після лікування; * p<0,001 порівняно з основною групою.

Проте кількість нападів стенокардії у хворих основної групи реєстрували значно рідше, ніж у пацієнтів групи порівняння $(p<0,001)$. Так, до початку лікування у хворих основної групи та групи порівняння кількість нападів стенокардії становила в се-

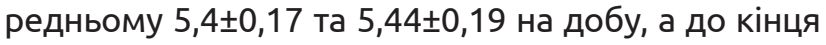


Огляди літератури, оригінальні дослідження, погляд на проблему, ювілеї

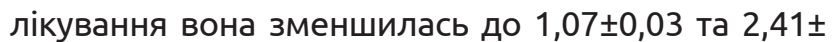
1,05. При цьому кількість нападів стенокардії у хворих, які приймали фруктозо-1,6-дифосфат, після

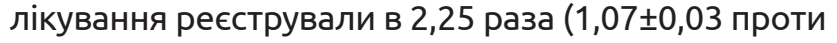
$2,41 \pm 1,05)$ рідше, ніж у хворих, які отримували лікування без додаткового призначення фруктозо-1,6дифосфату.

За даними добового моніторування ЕКГ, після проведеного лікування частота реєстрації епізодів депресії сегмента ST достовірно зменшила-

чCC

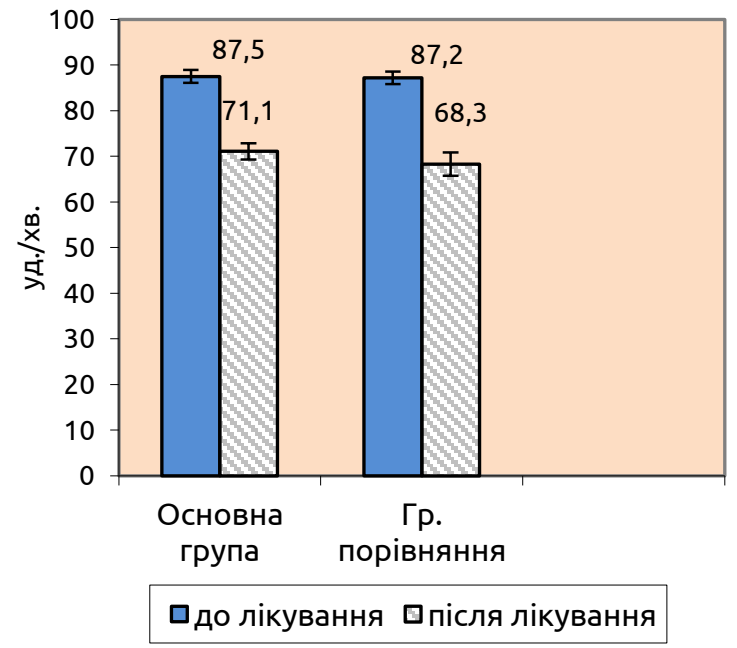

ся з 8,73 до 2,13 подій в основній групі та з 8,71 до $4,2$ в групі порівняння ( $<<0,001)$. При цьому у хворих основної групи частота подій депресії сегмента ST була достовірно нижчою, ніж у групі порівняння $(2,13 \pm 0,04$ проти 4,2 $20,06, p<0,05)$. Частота серцевих скорочень в основній групі достовірно зменшилась, порівняно з даним показником до лікування - як в основній $(3(87,5 \pm 0,7)$ уд./хв до $(71,1 \pm 0,9)$ уд./хв; р<0,001), так і в групі порівняння (з $(87,2 \pm 0,4)$ уд./хв до $(68,3 \pm 0,5)$ уд./хв; р<0,001) (рис. 2).

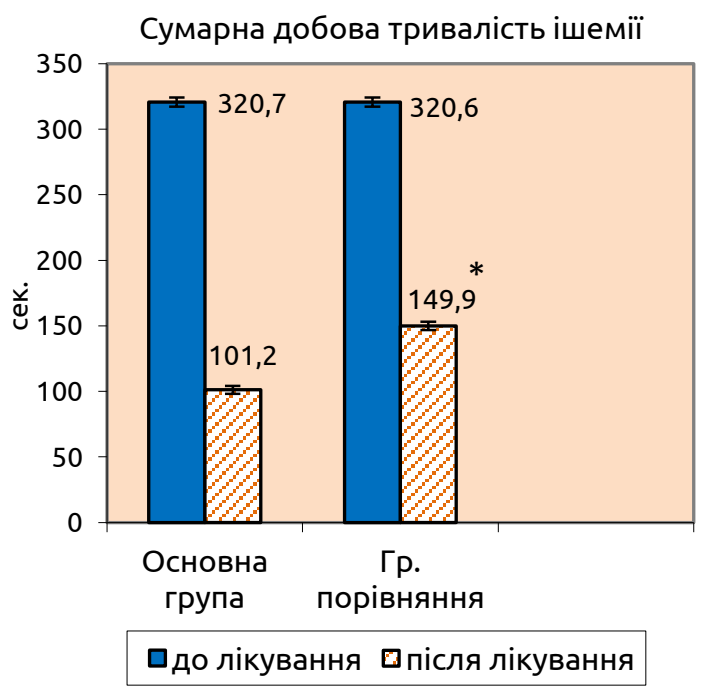

Рис. 2. Динаміка змін частоти серцевих скорочень та сумарної добової тривалості ішемії; * - p<0,001 порівняно з основною групою.

В обох групах знизилась сумарна добова тривалість ішемії, проте в основній групі цей показник був достовірно нижчим, ніж у групі порівняння.

Після лікування фібриляцію передсердь діагностували у 4 (8,3 \%) хворих основної групи та в 7 $(14,2$ \%) хворих групи порівняння. Суправентрикулярну екстрасистолію зустрічали у 8 (16,6 \%) хворих основної групи і в 10 (20,4%) пацієнтів групи порівняння. Шлуночкові порушення ритму реєстрували у 3 (6,25 \%) хворих основної групи та в 10 $(20,4 \%)$ пацієнтів групи порівняння. Небезпечних для життя шлуночкових порушень ритму після лікування в основній групі в жодному випадку не зареєстровано.

Після проведеної терапії вдалося досягти цільового рівня систолічного артеріального тиску в 69,2 \% хворих основної групи та в 65,4 \% пацієнтів групи порівняння ( $>>0,05$ між групами). Досягнення цільового рівня діастолічного артеріального тиску відмічено в 96,2 \% спостережень в основній і в 92,3\% - в групі порівняння ( $>0,05)$.

Таким чином, до лікування в обох групах хворі мали однакові скарги, а виразність клінічної симптоматики залежала від частоти серцевих скорочень, ступеня тяжкості ураження міокарда, тривалості епізодів порушення ритму. Спектр по- рушень ритму до лікування між групами також не мав відмінностей. В основній групі, порівняно $з$ групою порівняння, дещо більшою була питома вага небезпечних для життя шлуночкових аритмій $-18,1$ \% проти 15,5\%.

Аналізуючи вплив лікування на клінічний перебіг захворювання, ми виявили, що у пацієнтів основної групи покращення клінічного перебігу наставало швидше, ніж у хворих, які лікувались лише фіксованою комбінацією бісопрололу фумарату (5 мг) і амлодипіну (5 мг), без додаткового прийому D-фруктозо-1,6-дифосфату.

Достовірне зменшення після лікування $(1,07 \pm$

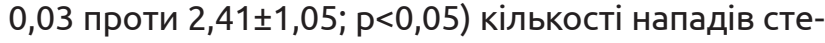
нокардії у хворих, які додатково приймали фруктозо-1,6-дифосфат, порівняно з хворими, в лікувальному комплексі яких фруктозо-1,6-дифосфат не використовували, вірогідно, пов'язано з додатковою антиішемічною дією препарату.

Після проведеного лікування вражала динаміка результатів добового моніторування ЕКГ. Зокрема, епізоди депресії сегмента ST у хворих основної групи реєстрували достовірно рідше, ніж у групі порівняння $(2,13 \pm 0,04$ проти 4,2 $\pm 0,06$; p<0,05). Сумарна добова тривалість ішемії значуще знизилась, і в основній групі цей показник був 
Огляди літератури, оригінальні дослідження, погляд на проблему, ювілеї

достовірно нижчим, ніж в групі порівняння. Це вказує на посилення антиангінальної дії шляхом додавання до комплексної терапії фруктозо-1,6дифосфату. Таким чином, зменшення кількості нападів стенокардії, подій депресії сегмента ST та сумарної добової тривалості ішемії є статистично більш значущим у хворих основної групи, ніж у пацієнтів групи порівняння.

Після лікування порушення ритму в основній групі реєстрували значно рідше, ніж в групі порівняння. А небезпечних для життя шлуночкових порушень ритму після лікування в основній групі не зареєстровано в жодному випадку.

Дані нашого дослідження підтверджуються результатами дослідження професора О. Сичова, яке доводить раціональність призначення в комплексній терапії хворих з шлуночковими аритміями і серцевою недостатністю фруктозо-1,6-дифосфату, завдяки його позитивному інотропному і антиаритмічному ефекту [10].

За даними нещодавно проведеного дослідження, додавання препарату D-фруктозо-1,6-дифосфату до складу комплексної терапії серцевої недостатності у хворих, які перенесли інфаркт міокарда, сприяє більш вираженому регресу клінічних симптомів серцевої недостатності та підвищенню толерантності до фізичного навантаження на фоні зниженої систолічної функції лівого шлуночка, що позитивно корелює $(r>0,73)$ зі збільшенням фракції викиду лівого шлуночка [14].

Отримані нами дані свідчать, що у хворих 3 AГ, IXC і порушеннями ритму серця при наявності гіпофосфатемії доцільним $\epsilon$ призначення D-фруктозо-1,6-дифосфату. Аналіз отриманих результатів показав, що у відповідь на лікування даної категорії хворих відбуваються позитивні зміни в покращенні клінічної симптоматики, зменшується кількість нападів стенокардії та подій депресії сегмента ST, відбуваються зміни чСС та зменшується сумарна добова тривалість ішемії, зміни щодо індексу часу САТ і ДАТ, позитивна динаміка таких порушень серцевого ритму, як фібриляція передсердь, суправентрикулярна екстрасистолія, шлуночкових порушень серцевого ритму, що загрожують життю.

Це дає змогу стверджувати, що включення в лікувальний комплекс D-фруктозо-1,6-дифосфату забезпечує істотний антиішемічний ефект у хворих на артеріальну гіпертензію в поєднанні 3 ішемічною хворобою та порушеннями ритму серця.

Отже, зміни метаболізму кардіоміоцитів при ішемії можуть відбуватися під впливом медикаментозної дії, зокрема за допомогою препаратів, здатних безпосередньо діяти на клітинний метаболізм. У такий спосіб дисфункцію міокарда та електрофізіологічних зрушень у вигляді змін сегмента ST на ЕКГ, появу загрудинного болю i, врешті, стенокардії як кінцевого етапу, в основі якого лежать зміни метаболізму міокарда, можна корегувати завдяки комплексній терапії зі включенням в лікувальний комплекс препарату, що забезпечує енерговитрати за рахунок доставки фруктозо-1,6-дифосфату в організм у готовому вигляді.

Висновки. Застосування комплексної терапії хворих на артеріальну гіпертензію в поєднанні $з$ ішемічною хворобою, порушеннями серцевого ритму і гіпофосфатемією із включенням в лікувальний комплекс D-фруктозо-1,6-дифосфату забезпечує істотний антиішемічний ефект, приводить до зменшення (в 2,25 раза) частоти нападів стенокардії, зменшення подій суправентрикулярної екстрасистолії, пароксизмів фібриляції передсердь, відсутності небезпечних для життя шлуночкових порушень ритму.

Перспективи подальших досліджень. Доцільне проведення рандомізованих клінічних досліджень із вивчення впливу гіпофосфатемії на перебіг артеріальної гіпертензії в поєднанні з ішемічною хворобою та порушеннями серцевого ритму з метою розробки терапії даної категорії хворих.

\section{Конфлікт інтересів відсутній.}

Conflicts of Interest: authors have no conflict of interest to declare.

\section{ЛІТЕРАТУРА}

1. Серцево-судинні захворювання. Класифікація, стандарти діагностики та лікування / В. М. Коваленко, М. І. Лутай, Ю. М. Сіренко, О. С. Сичов. - К., 2016. - 189 с.

2. Сиренко Ю. Н. Аттенто - новое слово в лечении артериальной гипертензии / Ю. Н. Сиренко, О. Л. Рековец // Артериальная гипертензия. - 2018. - № 1 (57). - С. 9-14.

3. Коваленко В. М. Проблеми здоров'я і тривалості життя в сучасних умовах : посібник / В. М. Коваленко, В. М. Корнацький, 2017. - С. 24-28.

4. Залежність електричної ектопічної активності серця від надмірної ваги тіла у хворих на гіпертонічну хворобу в поєднанні з ішемічною хворобою серця (за даними добового моніторування ЕКГ) / В. В. Сиволап, Л. О. Курілець, Н. Є. Добровольська, В. А. Матсалаєва // Патологія. - 2017. - Т. 14, № 1 (39). - С. 43-48.

5. Оптимізація лікування пацієнтів з артеріальною гіпертензією та супутньою ішемічною хворобою серця із застосуванням Тризипіну (мельдонію) / Ю. М. Сіренко, О. Л. Рековець, С. М. Кушнір [та ін.] // Артеріальна гіпертензія. - 2017. - Т. 1 (51). - С. 31-43.

6. Hypophosphatemia and duration of respiratory failure and mortality in critically ill patients / C. K. Feder- 
Огляди літератури, оригінальні дослідження, погляд на проблему, ювілеї

spiel, T. S. Itenov, K. Thormar [et al.] // Acta Anaesthesiologica Scandinavica. - 2018. - Vol. 62. - P. 1098-1104.

7. Clinical outcome of critically ill patients with thrombocytopenia and hypophosphatemia in the early stage of sepsis / E. Brotfain, A. Schwartz, A. Boniel [et al.] // Anaesthesiol Intensive Ther. - 2016. - Vol. 48, No. 5. P. 94-299.

8. Limited evidence for monitoring and treatment of hypophosphataemia in critically ill patients / C. Federspiel, T. S. Itenov, K. Thormar [et al.] // Ugeskr. Laeger. - 2015. Vol. 177, Issue 50.

9. Managing hypophosphatemia in critically ill patients: a report on an under-diagnosed electrolyte anomaly / A. Shajahan, J. Ajith Kumar, K. P. Gireesh Kumar [et al.] // J. Clin Pharm. Ther. - 2015. - Vol. 40, No. 3. - P. 353-354.

10. Сичов О. С. Нарушение ритма сердца: наиболее актуальные вопросы клинической практики [Електронний ресурс] / О. С. Сичов. // Укр. мед. часопис. - 2018. Retrieved from: https://www.umj.com.ua/article/127748/ narushenie-ritma-serdtsa-naibolee-aktualnye-voprosyklinicheskoj-praktiki.

\section{REFERENCES}

1. Kovalenko, V.M., Lutai, M.I., Sirenko, Yu.M. \& Sychov, O.S. (2016). Sertsevo-sudynni zakhvoriuvannia. Klasyfikatsiia, standarty diahnostyky ta likuvannia [Cardiovascular diseases. Classification, standard diagnostics and treatment]. Kyiv [in Ukrainian].

2. Sirenko, Yu.N., \& Rekovets, O.L. (2018). Attento novoye slovo $v$ lecheniyi arterialnoy gipertenzii [Attento a new word in the treatment of arterial hypertension]. Arterialnaya gipertenziya - Arterial Hypertension, 1 (57), 9-14 [in Russian].

3. Kovalenko, V.M., \& Kornatskyi V.M. (2017). Problemy zdorovia i tryvalosti zhyttia $v$ suchasnykh umovakh: posibnyk [Problems of health and life expectancy in modern conditions: manual]. [in Ukrainain].

4. Syvolap, V., Kurilets, L., Matsalaieva, V., \& Dobrovolska, N. (2017). Zalezhnist elektrychnoi ektopichnoi aktyvnosti sertsia vid nadmirnoi vahy tila u khvorykh na hipertonichnu khvorobu $v$ poiednanni z ishemichnoiu khvoroboiu sertsia (za danymy dobovoho monitoruvannia EKH) [The dependence of the ectopic electrical activity of the heart on the excess body weight in patients with essential hypertension in combination with ischemic heart disease (according to the daily ECG monitoring)]. Patolohiia - Pathology, 14, 1 (39). doi: 10.14739/2310-1237.2017.1.97795 [in Ukrainian].

5. Sirenko, Yu., Rekovets, O., Kushnir, S., Torbas, O., Havrylenko, T., \& Ryzhkova, N. (2017). Optymizatsiia likuvannia patsiientiv $z$ arterialnoiu hipertenziieiu ta suputnoiu ishemichnoiu khvoroboiu sertsia iz zastosuvanniam Tryzypinu (meldoniiu) [Optimizing the treatment of patients with arterial hypertension and concomitant coronary heart disease using Trizipin (meldonium)]. Arterialna hupertenziia - Aerterial Hypertension, 1 (51), 31-43. doi: 10.22141/2224-1485.1.51.2017.96249 [in Ukrainian].

6. Federspiel, C., Itenov, T., Thormar, K., Liu, K., \& Bestle, M. (2018). Hypophosphatemia and duration of respiratory failure and mortality in critically ill patients. Acta Anaesthesiologica Scandinavica, 62 (8), 1098-1104. doi: $10.1111 /$ aas. 13136
11. 2013 ESH/ESC Guidelines for the management of arterial hypertension: The Task Force for the management of arterial hypertension of the European Society of Hypertension (ESH) and of the European Society of Cardiology (ESC) // European Heart Journal. - 2013. - Vol. 34. - P. 2159-2219.

12. ESC/ESH Guidelines for the management of arterial hypertension / B. Williams, W. Bryan, M. Giuseppe [et al.] // European Heart Journal. - 2018. - Vol. 39, Issue 33. P. 3021-3104.

13. Working Group on the Summit on Combination Therapy for CVD. Combination pharmacotherapy to prevent cardiovascular disease: present status and challenges / Working Group on the Summit on Combination Therapy for CVD // European Heart Journal. - 2013. - Vol. 35. - P. 353-364.

14. Скрипник І. М. Вплив препарату Езафосфіна на перебіг серцевої недостатності у післяінфарктний період [Електронний ресурс] / І. М. Скрипник, Т. В. Дубровінська, Н. О. Люлька // Укр. мед. часопис. - 2017, 9 лютого. - Режим доступу: https://www.umj.com.ua/article/ 105015/vpliv-preparatu-ezafosfina-na-perebig-sertsevoyinedostatnosti-u-pislyainfarktnij-period [in Ukrainian].

7. Brotfain, E., Schwartz, A., Boniel, A., Koyfman, L., Boyko, M., Kutz, R., \& Klein, M. (2016). Clinical outcome of critically ill patients with thrombocytopenia and hypophosphatemia in the early stage of sepsis. Anethesoil. Intensive Ther., 48 (5), 294-299. doi: 10.5603/ait.a2016.0053

8. Federspiel C., Itenov T.S., Thormar K., \& Bestle M.H. (2015). Limited evidence for monitoring and treatment of hypophosphataemia in critically ill patients. Ugeskr Laeger, 177 (50).

9. Shajahan, A., Ajith Kumar, J., Gireesh Kumar, K., Sreekrishnan, T., \& Jismy, K. (2015). Managing hypophosphatemia in critically ill patients: a report on an under-diagnosed electrolyte anomaly. Journal of Clinical Pharmacy and Therapeutics, 40 (3), 353-354. doi: 10.1111/jcpt.12264

10. Sychev, O. S. (2018). Narusheniye ritma serdtsa: naiboleye aktualnyye voprosy klinicheskoy praktiki [Heart rhythm disorder: the most pressing issues of clinical practice]. Ukr. Med. Chasopys - Ukr. Medical Chronicle. Retrieved from: https://www.umj.com.ua/article/127748/narushenie-ritmaserdtsa-naibolee-aktualnye-voprosy-klinicheskoj-praktiki [in Russian].

11. ESH/ESC. (2013). Guidelines for the management of arterial hypertension. European Heart Journal, 34 (28), 2159 to 2219 Doi:10.1093/eurheartj/eht151

12. Williams, B., Bryan, W., Giuseppe, M., \& Wilko, S. (2018). ESC/ESH Guidelines for the management of arterial hypertension. European Heart Journal, 39 (33), 3021-3104.

13. (2013). Combination pharmacotherapy to prevent cardiovascular disease: present status and challenges. European Heart Journal, 35 (6), 353-364. doi: 10.1093/eurheartj/eht407

14. Skrypnyk, I.M., Dubrovinska, T.V., \& Liulka, N.O. (2017). Vplyv preparatu Ezafosfina na perebih sertsevoi nedostatnosti u pisliainfarktnyi period [Influence of the drug Esafosfina on the course of heart failure in patients in postinfarction period]. Ukr. med. chasopys - Ukrainian Medical Chronicle. Retrieved from: https://www.umj.com.ua/article/105015/vpliv-preparatu-ezafosfina-na-perebig-sertsevoyi-nedostatnosti-u-pislyainfarktnij-period [in Ukrainian]. 


\title{
Огляди літератури, оригінальні дослідження, погляд на проблему, ювілеї КОМПЛЕКСНОЕ ЛЕЧЕНИЕ АРТЕРИАЛЬНОЙ ГИПЕРТЕНЗИИ В СОЧЕТАНИИ С ИШЕМИЧЕСКОЙ БОЛЕЗНЬЮ И НАРУШЕНИЯМИ СЕРДЕЧНОГО РИТМА
}

\author{
๑С. А. Шейко, Н. А. Колб \\ ГУ «Днепропетровская медицинская академия МЗ Украины»
}

РЕЗЮМЕ. В комплексном лечении АГ в сочетании с хронической ИБС наиболее целесообразно применять средства, которые благоприятно влияют на течение обоих заболеваний: снижают уровень АД, предотвращают развитие ишемии и стенокардии, инфаркта миокарда и инсульта, уменьшают вероятность смерти, улучшают качество жизни больных. Но лечение коморбидных пациентов с АГ, ИБС и нарушениями сердечного ритма на фоне гипофосфатемии в настоящее время остается не до конца изученным.

Цель работы - изучение клинической эффективности комплексного лечения пациентов пожилого возраста с артериальной гипертензией (АГ), ишемической болезнью сердца (ИБС) и нарушениями сердечного ритма на фоне гипофосфатемии.

Материал и методы. Проведен анализ лечения 353 пациентов в возрасте $(71,2 \pm 4,5)$ лет с АГ и ИБС, получавших базисную терапию. Из них у 97 (50 женщин и 47 мужчин) больных с АГ, ИБС, нарушениями сердечного ритма и гипофосфатемией сохранялось нестабильное течение АГ и сердечно-болевые приступы. В основную группу включены 48 пациентов (25 женщин и 23 мужчины), которые принимали фиксированную комбинацию бисопролола фумарата (5 мг) с амлодипином (5 мг) и фруктозо-1,6-дифосфат. В группу сравнения вошли 49 больных (24 женщины и 25 мужчин), в лечебный комплекс которых D-фруктозо-1,6-дифосфат не включали. Проведены общеклиническое обследование, определение электролитов крови, электрокардиография (ЭКГ), суточное мониторирование ЭКГ и артериального давления (АД). Гипофосфатемию диагностировали при уровне фосфора в сыворотке крови <0,9 ммоль/л.

Результаты. После лечения приступов стенокардии регистрировали в 2,25 раза реже $(1,07 \pm 0,03$ против $2,41 \pm 1,05)$, событий депрессии сегмента ST регистрировали достоверно меньше у больных основной групы относительно таковых в групе сравнения $(2,13 \pm 0,04$ против 4,2 20,06$)$. Фибрилляцию предсердий диагностировали у 4 (8,3 \%) больных основной и у 7 (14,2 \%) - группы сравнения, суправентрикулярную экстрасистолию регистрировали у 8 (16,6 \%) больных основной и у 10 (20,4 \%) пациентов группы сравнения, желудочковые аритмии - у 3 (6,25 \%) больных основной группы и у 10 (20,4 \%) больных группы сравнения. Опасные для жизни желудочковые нарушения ритма после лечения в основной группе не зарегистрированы ни в едином случае.

Выводы. Применение комплексной терапии при АГ с ИБС, нарушениями сердечного ритма и гипофосфатемией с включением в лечебный комплекс D-фруктозо-1,6-дифосфата обеспечивает существенный антиишемический эффект, приводит к уменьшению (в 2, 25 раза) частоты приступов стенокардии, событий суправентрикулярной экстрасистолии, пароксизмов фибрилляции предсердий, предотвращает возникновение опасных для жизни желудочковых нарушений ритма.

КЛЮчЕВЫЕ СЛОВА: артериальная гипертензия; ишемическая болезнь сердца; нарушения сердечного ритма; фруктозо-1,6-дифосфат.

\section{COMPREHENSIVE TREATMENT OF ARTERIAL HYPERTENSION COMBINED WITH ISCHEMIC DISEASE AND HEART RHYTHM DISORDERS}

๑S. O. Sheiko, N. O. Kolb

\section{Dnipropetrovsk Medical Academy}

SUMMARY. In the complex treatment of hypertension in combination with chronic coronary artery disease, it is most appropriate to use means that have a beneficial effect on the course of both diseases: to lower the level of blood pressure, to prevent ischemia and angina, myocardial infarction and stroke, to reduce the likelihood of death, to improve the quality of life of patients. But the treatment of comorbid patients with hypertension, coronary artery disease, and cardiac arrhythmias in the background of hypophosphatemia is currently not completely determined.

The aim of the study - the clinical efficacy of complex treatment in patients with hypertension in combination with coronary heart disease and cardiac rhythm disorders in the background of hypophosphatemia.

Material and Methods. The analysis of treatment of 353 patients aged $(71.2 \pm 4.5)$ years with hypertension and coronary heart disease, received baseline therapy. Among them, 97 (50 women and 47 men) patients with hypertension, coronary heart disease, heart rhythm disorders and hypophosphataemia maintained an unstable course of hypertension and cardio-pain attacks. The main group included 48 patients ( 25 women and 23 men) who received a fixed combination of bisoprolol fumarate $(5 \mathrm{mg})$ with amlodipine $(5 \mathrm{mg})$ and fructose-1,6-diphosphate. The comparison group included 49 patients (24 women and 25 men), whose D-fructose-1,6-diphosphate was not added to the treatment complex. A generalclinical examination, blood electrolytes, electrocardiography (ECG), daily ECG monitoring and blood pressure (BP) were performed. Hypophosphatemia was diagnosed at serum phosphorus level $<0.9 \mathrm{mmol} / \mathrm{l}$. 
Огляди літератури, оригінальні дослідження, погляд на проблему, ювілеї

Results. After treatment, the number of angina attacks was recorded 2.25 times $(1.07 \pm 0.03)$ versus $(2.41 \pm 1.05)$ less frequently, depression events of the ST segment were significantly lower (2.13 versus 4.2 ) in patients with the main group, compared with those in the comparison group. The achievement of the target level of systolic blood pressure was noted in $69.2 \%$ of the patients in the main group and $65.4 \%$ in the comparison group ( $<<0.05$ among the groups). Atrial fibrillation was diagnosed in 4 (8.3\%) patients in the primary and 7 (14.2\%) in the comparison group. Supraventricular extrasystole was recorded in 8 (16.6 \%) patients in the primary and in 10 (20.4\%) patients in the comparison group. Ventricular arrhythmias - in 3 (6.25\%) patients of the primary and 10 (20.4\%) of the comparison group. Dangerous ventricular rhythm disturbances after treatment in the main group have not been registered in any case.

Conclusions. The application of complex therapy for patients with arterial hypertension in combination with ischemic disease, heart rhythm disturbances and hypophosphatemia with inclusion in the treatment complex D-fructose1,6-diphosphate provides a significant anti-ischemic effect, which leads to a decrease (in 2.25 times) of the frequency of angina attacks, reduction of supraventricular extrasystoles, paroxysms of atrial fibrillation, absence of ventricular rhythm dangerous for life.

KEY WORDS: arterial hypertension; coronary heart disease; cardiac arrhythmias; fructose-1,6-diphosphate.

Отримано 11.02.2019 